\title{
SIZE AND SOCIODEMOGRAPHIC CHARACTERISTICS OF THE AFGHAN REFUGEE POPULATION IN PAKISTAN
}

\author{
FARHAT Y'SUE

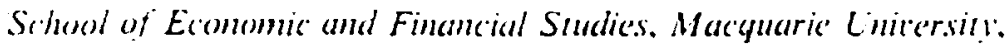 \\ Sirine'l. Australia
}

\begin{abstract}
Summary. Some recent data are presented on the size and selected sociodemographic characteristics of the Afghan refuges population in Pakistan. Altinough the official figures show that there were 3.27 million registered $A$ fohan refugees in Pakistan. it is estimated that the actual number maly be as high as $\$ .6$ million. There is an excess of females over males. mainly due to "war-reiated activities and excessive casualties particularly among males. Whils infant and childhood mortality rates are declining and are lower than the levels prevalent in Pakistan. as well as in Afghanistan during the prewar period, the fertility levels among Afghan refugees seem very high indeed.
\end{abstract}

\section{Introduction}

Relatively small movements of population. particularly of nomads. have been going on for centuries between Afghanistan and Pakistan. However. the influx of Afghan refugees since the Communist coup in December 1978 has been phenomenal, both in size and in its effects on the social and economic conditions in Pakistan. According to recent estimates. the Afghan refugees constitute the largest group of refugees in the worid and the majority of them are in Pakistan.

This paper presents some recent data on the size and sociodemographic characteristics of Afghan refugees in Pakistan: mosi of the data were collected during a mission the author undertook in January 1989 on behalf of the United Nations Population Fund. There are two major sources of demographic data for Alghan refugees in Pakistan: the registration system introduced by the Government of Pakistan in 1979. and sample surveys conducted by rarious United Nations agencies and non-governmental organizations.

For purposes of comparison. it was important to obtain similar demographic data for the population of Afghanistan. No recent data were available but the aluthor was allowed access to the report of the National Demographic and Family Guidance Survey of the Settled Population of Afghanistan which provided demographic data for 1972-73) (Hakimi \& Graham. 1975). 


\section{Data on Afghan refugees}

Registrationl data

There are two types of $A$ fghan refugees in Pakistan: those who are registered with the Government of Pakistan and those who are not registered. While statistics are available for the former there is very little information about the number and characteristics of the latter. This is largely hecaluse most of the unregistered refugees have settled in the urban areas of Pakistan. where they seem to have integrated with the Pakistani population. According to some estimates there may be up to half a million unregistered refugces living in Pakistan (Jensen. 1989).

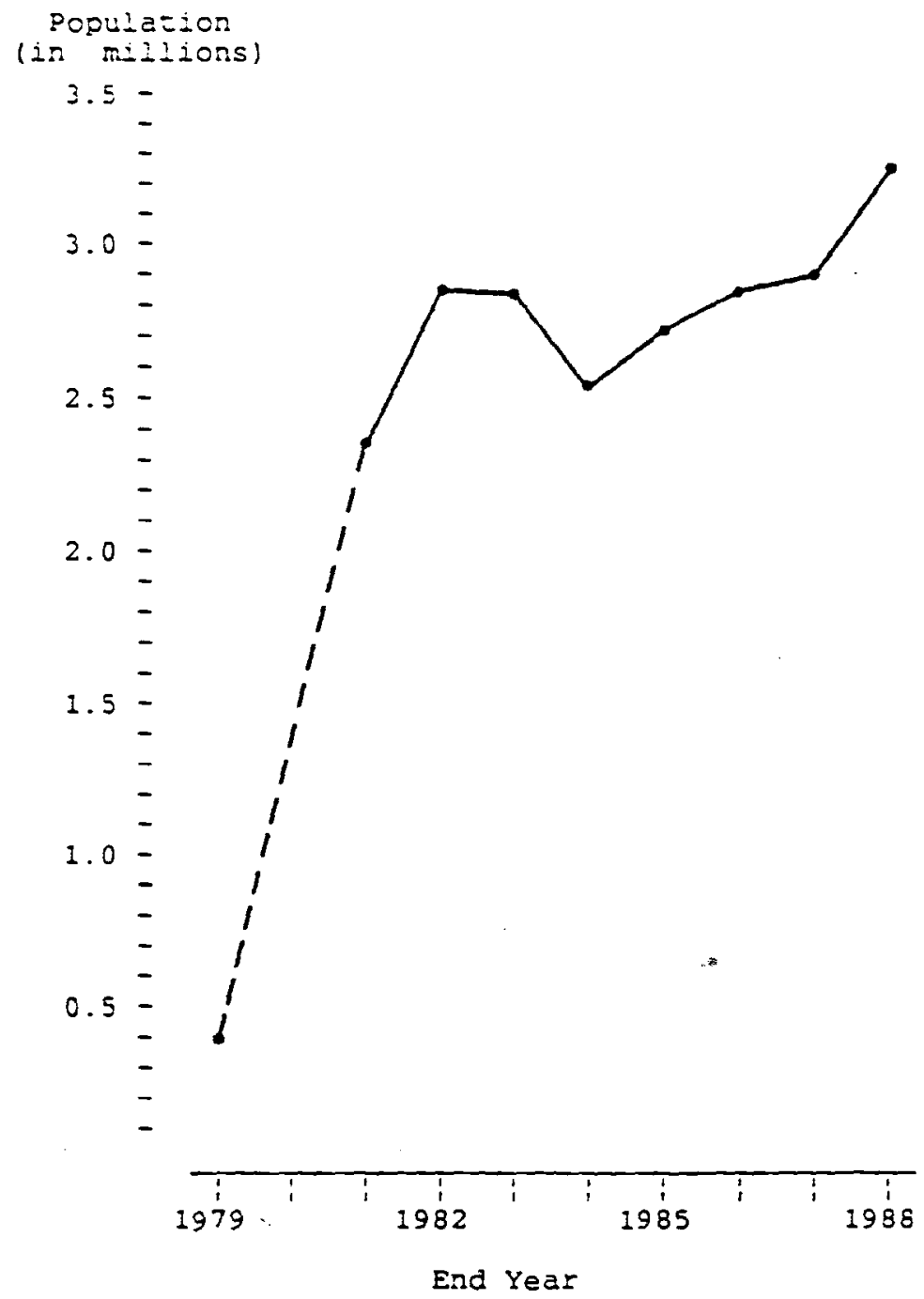

Fig. I. Registered population of Afghan refugees in Pakistan. end of year 1979-1988. 
As most of the Afghan refugees come fo Pakistan in family groups. cach family is issued with a registration document called the passbook. In order to obtain this. the head of the family has to produce a certificate duly signed and attested by a representative of one of the recognized political parties of Afghan refugees. This docunient contains the photograph and particulars of the head of the family along with the name. sex. age and the relationship to the head. of wach family member. The Refugee Village Administrator keeps the original certificate provided by the family. $H:$ also records the particulars of each family on the individual reference card which he heeps. Each month he sends to the Distric: Adminisirator a statement of the total number of registered families and the total registered population in his camp. together with the numbers of adult males. adult females and children. The data provided by each camp are consolidated into district. provincial and national summaries.

Figure I shows the registered population of Aighan refugees for the 9-year period ending 31 December. 1988. As expected. the numbers have been increasing. with the exception of 1983 and 1984 . The apparent decline in those years was due to the special efforts made by the Goternment of Pakistan to improve the accuracy of registration data: these included the re-anumeration of Afghans living in refugee camps. and the general tightening of the registration procedures in order to ensure that only bona fide refugess uere being registered.

Some statistics derived from the official data on registered Afghan refugees (Table $1 /$ show first. that children constituted more than half of the population of refugee camps. and secondly that there was a surplus of adult females in the refugee nopulation-the sex ratio was 88 adult males per 100 adult females. Given that the overall sex ratio in Afghanistan before the war was around 116 males per 100 females Table 1 and that the sex ratio for the rural population aged 10 and over was close to 123 (Hakimi \& Graham. 1975). the observed surplus of adult females among the Afghan refugees is most likely to be explained by a higher number of war-related casualties among Afghan males, or by differential emigration.

From discussions with the officials from the United Nations High Commissioner for Refugees. the World Food Programme and other agencies it seems that there are inaccuracies in the official registration data. The causes include: some families hold multiple passbooks: some absent family members are registered as present; 'ghost families. i.e. families who had left camps without having their passbooks cancelled; babies born to Afghan refugees in Pakistan are not being registered: the imposition of a maximum limit of seven members per family who could be registered. irrespective of the actual size of the refugee family. It is obvious that the first three of these problems would have an inflationary effect on the estimated population of registered Afghan refugees in Pakistan, while the last two would have the opposite effect. The effect of the last two may be assessed as follow's.

If one assumes that the registered population of Afghan refugees at the end of 1981 was 2 million instead of the reported 2.375 million, and that the crude birth rate was around 50 births per 1000 population per annum. then over the past 7 years at least 700.000 births must have occurred in the refugee camps. The assumed crude birth rate is based on the fact that in Afghanistan in 1972-73 it was 43 births per 1000 population per annum (Appendix Table A). Moreover, there is some evidence that the fertility of Afghan women in refugee camps is quite high; for example, Krijgh (1987) 
Table 1. Statistics on Afghan refugees registered in Pakistan. 31 December 1988

\begin{tabular}{|c|c|c|c|c|c|c|c|c|c|}
\hline \multirow[b]{3}{*}{ Ared } & \multirow{2}{*}{\multicolumn{2}{|c|}{ Camps }} & \multicolumn{5}{|c|}{ Population } & \multirow{2}{*}{\multicolumn{2}{|c|}{$\begin{array}{c}\text { Average } \\
\text { size }\end{array}$}} \\
\hline & & & \multicolumn{2}{|c|}{ Total } & \multicolumn{2}{|c|}{$\underset{\substack{0 \\
0}}{\text { Adults }}$} & \multirow{2}{*}{$\begin{array}{c}\text { Child- } \\
\text { ren } \\
\%\end{array}$} & & \\
\hline & $N$ & $\%$ & $(000 s)$ & $\%$ & $M$ & $\mathrm{~F}$ & & Camps & Family \\
\hline Paisistan & 345 & 100 & 3.271 & $100-0$ & 23 & 26 & 51 & 9.000 & $6: 20$ \\
\hline NHFP & 251 & 73 & 2.237 & $68 \cdot 4$ & 23 & 26 & 51 & 9.000 & 6.22 \\
\hline Settled Districts & 155 & 45 & 1.366 & $41 \cdot 8$ & 22 & 26 & 52 & 9.000 & $5 \cdot 87$ \\
\hline Ahintabad & 18 & 5 & 143 & $4 \cdot 4$ & 15 & 23 & 62 & 8.000 & 6.02 \\
\hline Bannu & 7 & 2 & 74 & 23 & 21 & 27 & $5 ?$ & 11.000 & 6.89 \\
\hline Cinitral & 3 & $*$ & 38 & $1 \cdot 2$ & 23 & 31 & 46 & $13.0 \times 10$ & $5 \cdot 81$ \\
\hline Dir & 10 & 3 & 90 & 2.7 & 19 & 28 & 53 & 9.000 & 5.70 \\
\hline D. ! Khan & 11 & 3 & 88 & 2.7 & 21 & 28 & 52 & 8.000 & 6.77 \\
\hline Kunat & 18 & 5 & 230 & 7.0 & 25 & 28 & 46 & 13.000 & $7 \cdot 15$ \\
\hline Mansehra & 9 & 3 & 72 & $2 \cdot 2$ & 13 & 20 & 68 & 8.000 & $7 \cdot 06$ \\
\hline Mardan & 17 & 5 & 107 & $3 \cdot 3$ & 21 & 27 & 52 & 6.000 & 5.92 \\
\hline Pesnawar-I & 31 & 9 & 283 & $8 \cdot 7$ & 23 & 26 & 50 & 9.000 & $4 \cdot 88$ \\
\hline Peshutuar-II & 29 & 8 & 226 & 6.9 & 25 & 24 & 51 & 8.000 & $5-41$ \\
\hline Shat & 2 & $*$ & 14 & $0-i$ & 18 & 29 & 53 & 7.000 & 5.55 \\
\hline Trioal Agencies & 96 & 28 & 870 & $26 \cdot 6$ & 25 & 27 & 48 & 9.000 & 6.85 \\
\hline Batiur & 25 & 7 & 198 & $6 \cdot 1$ & 24 & 29 & 47 & 8.000 & 6.95 \\
\hline Kurram & 34 & 10 & 348 & $10 \cdot 6$ & 29 & 28 & 43 & 10.000 & $6 \cdot 85$ \\
\hline Maiakand & 3 & $*$ & 55 & $1 \cdot 7$ & 14 & 26 & 60 & 18.000 & 6.95 \\
\hline Monmand & 2 & $*$ & 16 & 0.5 & 29 & 32 & 40 & 8.000 & 6.00 \\
\hline N. Waziristan & 24 & 7 & 184 & $5 \cdot 6$ & 25 & 23 & 51 & 8.000 & $7 \cdot 03$ \\
\hline Orakzai & 2 & $*$ & 13 & 0.4 & 20 & 37 & 43 & 7,000 & 6.77 \\
\hline S. Waziristan & 6 & 2 & 57 & 1.7 & 21 & 24 & 55 & 9.000 & $6 \cdot 17$ \\
\hline Balucinistan & 77 & 22 & 836 & 25.5 & 23 & 27 & 50 & 11.000 & $6 \cdot 27$ \\
\hline Chagai & 21 & 6 & 172 & $5 \cdot 3$ & 23 & 27 & 50 & 8.000 & 6.02 \\
\hline Guilistan & 12 & 3 & 172 & $5 \cdot 2$ & 23 & 27 & 50 & 14.000 & $6 \cdot 48$ \\
\hline Loralai & 10 & 3 & 105 & $3 \cdot 2$ & 23 & 27 & 50 & 11.000 & $6 \cdot 20$ \\
\hline Pishin & 19 & 6 & 169 & 52 & 23 & 27 & 50 & 9.000 & 6.59 \\
\hline Quetua & 5 & 1 & 121 & 3.7 & 23 & 27 & 50 & 24.000 & 5.93 \\
\hline Zhob & 5 & 1 & 55 & 1.7 & 23 & 27 & 50 & 11.000 & 6.06 \\
\hline Chaman & 5 & 1 & 42 & $1 \cdot 3$ & 23 & 27 & 50 & 8.000 & 6.86 \\
\hline Punjab" & 16 & 5 & 180 & $5 \cdot 5$ & 16 & 23 & 61 & 11.000 & 5.67 \\
\hline $\operatorname{Sind}_{+}$ & 1 & * & 19 & 0.6 & 24 & 28 & 48 & 19.000 & 6.23 \\
\hline
\end{tabular}

* Less than $1 \%$

† Kot Chandna, District Mianwali.

¥ Karachi.

$\$$ To nearest thousand. 
reported a total marital ierility rate of 158 from her surve! of uomen living in retugec camps in Kohat district in Vorth West Frontier Province (NWFP). Even allowing for infant and childhood mortality. it is likely that at least $550-600.000$ of these Pakistan-born Afghan children must be alive and should have been included in the registered population of Afghan refugees.

The restriction placed on the number of family members not to exceed seven has resulted in an average family size for registered Alghans of 6 -2 persons. A study by the Lnited Nations Rescarch Institute for Social Development (LNRISD) in 1986 showed that the average size of a houschold was 8.5 /Christensen d Scott. 19881. Although the detinition of the houschold in that study may be difierent from that of the family as given in the official statistics. it is unlikely that these were very different. The LNRISD study did not distinguish between the registered and unregistered popie living in the camps. and from its findings. it appears that the average size of a family calculated from the official registration statistics was underestimated by $2 \cdot 3$ members per family. Although the reported number of refugec lamilies living in camps was 527.923 at the end of 1955 . even allowing for the ghosi families by say 20\%" and for differences in the definitions of housenolds and lamilies. the true number of famiiies living in reiugee camps at that date must be around 422.000 . If the LNRISD estimate of average size of 8.5 is correct. thers must have been about 3.6 million Afghan refugees living in camps at the end of 1988.

Information on age of the family members was recorded at the time of registration. but was not compiled. During his visits to the refugec canps the author noted that the information on age. although suffering from the usual problems of misreporting and digital preference. was easily accessible from the registration documents. It is unfortunate that this information was not deemed important enough by the Government of Pakistan or the UN agencies to be compiled for planning purposes. This is perhaps one of the biggest gaps in the official registration statistics. On the other hand. information on refugees places of origin in Afghanistan and tribes to which they belonged. is being compiled and will certainly be useful in planning for the repatriation of Afghan refugees from Pakistan.

\section{Surtel data on .Afghan refugees}

Seven sample surveys have been conducted on various aspects of the population of Afghan refugees in Pakistan. The first three. dealing with infant mortality and childhood nutritional status were carried out by the Centres for Disease Control (CDC) of the LS Public Health Service in 1984. 1985 and 1986. Two similar, but somewhat localized. surveys on the health status of Afghan women and children were conducted by the International Rescue Committee (IRC) in 1986 and 1987. A survey on social and economic conditions of Afghan refugees was completed in 1986 by the UNRISD, and finally. a survey concerned with the estimation of war related casualties among Afghan refugees was conducted by Gallup Pakistan in 1987. The CDC and UNRISD surveys were sponsored by the United Nations High Commission for Refugees, while the remainder were funded by various nongovernmental organizations.

The CDC surte is. These surveys aimed to assess the current infant and neonatal mortality and childhood under-nutrition among Afghan refugees. Samples of 
chitdren. (1-4 years of age were drawn for the 1984, 1985 and 1986 surveys numbering respectively 2136,2425 and 2439 children. A two-stagc, random start, cluster sampling method was used in all three surveys. The first stage identified the specific refugec camps where sample clusters were located, while in the second stage the particular houscholds within the sampled clusters were identified. The sampling frame was intended to include all Afghan refugees living in camps in Pakistan. Interviewing of respondents, who were all females. was done by three teams of three-four lady health visitors during the months of April and May.

Comparison of the three CDC surveys (Table 2) shows a substantial decrease in neonatal and infant mortality and improvement in nutritional status of the Afghan refugee children over the 3-year period. Moreover. the proportion of children suffering from diarrhoea. during the week prior to the intervieu, had declined, while the proportion of children who had had BCG vaccination had increased. The $95 \%$ confidence intervals for the annual estimates of infant mortality rates overlap and therefore it is difficult to say conclusively that the observed decline uas statistically: significant. The report simply ciams that the observed changes are real.

Substantial differences were observed between refugee camps in NWFP Punjab and Baluchistan. The 1986 survey. in which over-sampling was done in Baluchistan so as to obtain more robust estimates for that province. confirmed the earlier findings that the infant mortality rate in Baluchistan was up to $70 \%$ higher than the levels prevalent in refugee camps elsewhere in Pakistan. Although no differences in levels of neonatal mortality were observed. diarrhoea prior to death was experienced by $57 \%$ of the post-neonatal infant deaths among refugees in Baluchistan. and undernutrition among refugee children in Baluchistan was more prevalent than in NWFP Punjab.

If the CDC trend is real then the infant mortality rate among Afghan refugees in Pakistan in 1986 was $28 \%$ lower than that in Pakistan as a whole: 112 infant deaths per 1000 live births during 1984-86 (Rukanuudin \& Farooqui, 1988). From

Table 2. Results from the CDC surveys among Afghan refugees, 1984-86

\begin{tabular}{|c|c|c|c|}
\hline Parameter & 1984 & 1985 & 1986 \\
\hline Total children $<5$ years old & 2136 & 2425 & 2439 \\
\hline Live births in past 12 months & 595 & 632 & 627 \\
\hline Inlant dwaths in past 12 months & 92 & 75 & 51 \\
\hline Infunt mortality rate (per 1000 ) & 156 & 119 & 81 \\
\hline Neonatal mortality rate (per 1000 ) & $6 !$ & 46 & 40 \\
\hline \% of children dying before 5 th birthday & 23 & 19 & 12 \\
\hline$\%$ of children with diarrhoea & \multicolumn{2}{|c|}{$\Rightarrow$} & \\
\hline in past 7 dậs & 38 & 35 & 28 \\
\hline$\%$ of children with BCG scar & * & 41 & 55 \\
\hline \multicolumn{4}{|l|}{$\%$ of children weighed } \\
\hline$\geq$ median $w_{l}$ & 26 & 35 & 42 \\
\hline$<80^{\circ} \%$ of median wt & 4 & 2 & 2 \\
\hline
\end{tabular}

Source: Boss \& Lewis (undated). 
discussions with various persons associated with the provision of health services for Aghan refugees the author was unabie to find reasons for this difference in infant mortality levels.

The IRC survels. The two IRC surveys had objectives very similar to those of the CDC survess. excepl that in the 1987 survey information on pregnancy and childbirth. inciuding some questions on child spacing. were also asked. These surveys were conducted in Afghan refugec camps in Kohat district. NWFP. Where IRC operates. The method of the IRC survess was similar to the CDC. except that the questionnare used in the former was much more detailed.

In the IRC surveys. while neonatal nortality remained more or less constant Table 31. intant mortality substantially declined. though agisin the $95^{\circ}$ " confidence intervals for the 1986 and 1987 infant mortality rates overlapped. Overall the findings of these surveys were similar to those of the CDC surveys.

Perhaps one of the most important contributions of the IRC survels was the stimation of fertility of Afghan refugee women and the information on family pianning. The estimated total marital fertiit! rate was nearly 14 (Tabic i). and the general fertiily rate was about 400 per 1000 women. These very high levels of fertility are at least partially corroborated by population pyramids (Fig. 2).

Some of the other important findings are: nearly $24^{\circ}$ of all women were pregnant at the time of interview. and an additional $6 \%$ thought the were in the first months of pregnancy: about one in four women had experienced one or more miscarriages or stillbirths: $43 \%$ of all women wanted trained assistance arailable during their deliveries (actually $75 \%$ were assisted by their mothers or close female relatives); thirteen out of every 1000 women reported a maternal death among their relatives: $44^{n} ;$ of respondents favoured the idea of child spacing but described their reasons for

Table 3. Results from the IRC survey's among Afghan refugees in Kohat District

\begin{tabular}{|c|c|c|}
\hline Parameter & $19 \$ 6$ & 1987 \\
\hline Total children $<5$ yeirs old & 888 & 997 \\
\hline Live births in past 12 months & 246 & 270 \\
\hline Infant deaths in past 12 moniths & 27 & 19 \\
\hline Infant mortality rate (per 1000 ) & 87 & 52 \\
\hline Veonatal mortality rate (per 1000 ) & 21 & 22 \\
\hline$\%$ of children dying before sth birthday & 12 & 10 \\
\hline$\%$ of children with diarrhoca & 40 & 28 \\
\hline \% of children with BCG scar & 69 & 79 \\
\hline Total number of women & 588 & 674 \\
\hline General fertility rate iper 1000 ) & $\$ 18$ & 400 \\
\hline Tolal marital fertility rate & * & $13 \cdot 6$ \\
\hline Compounds using improved water supply & 32 & 65 \\
\hline Compounds with kitchen gardens & 35 & 36 \\
\hline Compounds with poultry livestock & 52 & 100 \\
\hline Compounds with ventilated improved pit latrines & 43 & 46 \\
\hline
\end{tabular}




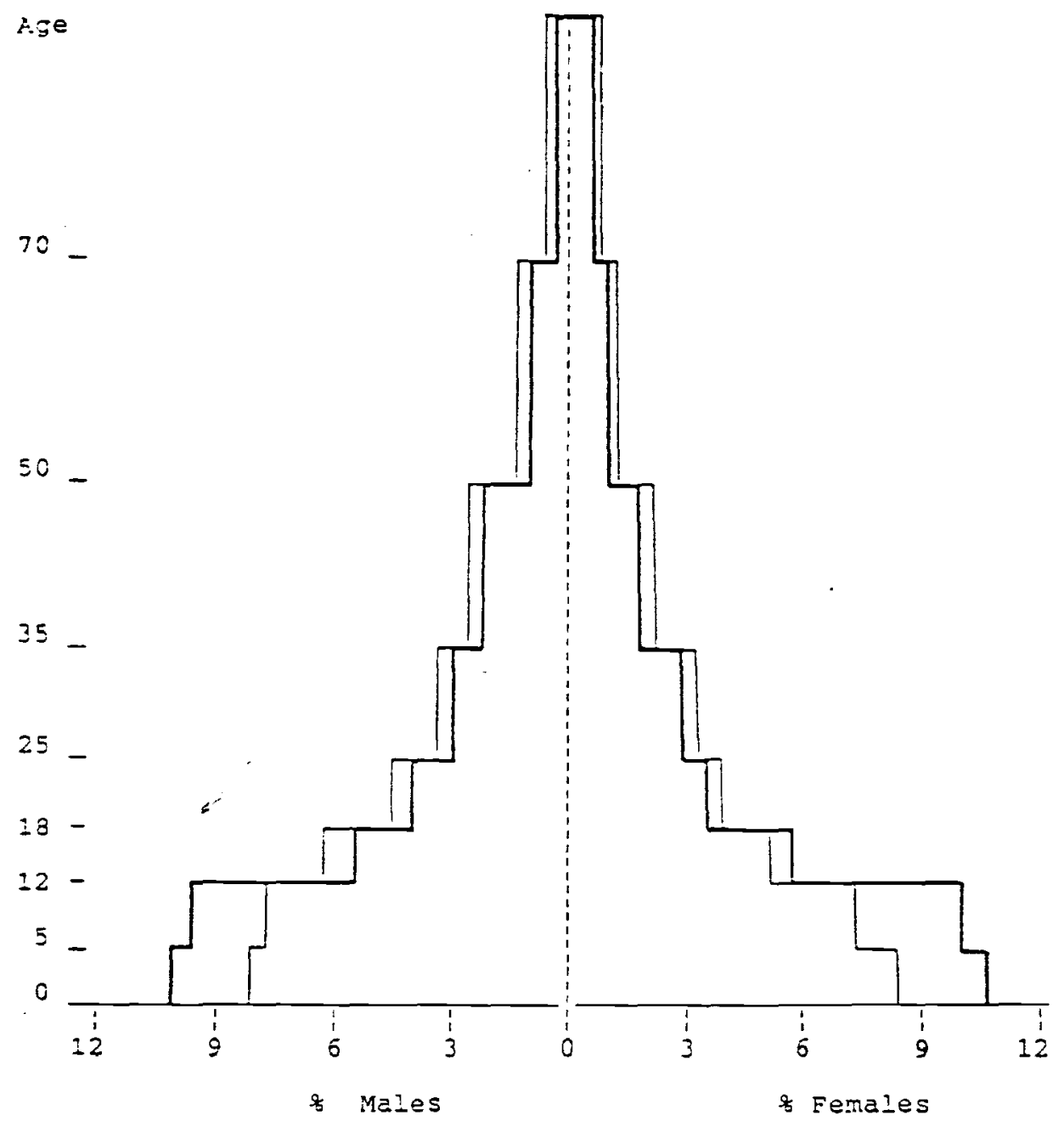

Fig. 2. Population pyramids for Afghanistan (1972-73) and for Afghan refugees in Pakistan (1986).

not using contraception. Some reasons were: $13 \%$ had only 'few' children; $16 \%$ were not permitted by the husband or mother or mother-in-law: $4 \%$ had no need as the husband was away: $3 \%$ were too young. Fifteen per cent of respondents like the idea of birth spacing and $3 \%$ had used or were currently using a method of contraception. Thirty-three per cent of respondents were against contraception and wanted more children. 
It is noi possibie to comment on the accuract or otherwise of these findings. particulariy regading family planning attitudes and practices. However discussions with many doctors and the health visitors. active in the provision of health services anong $:$ f ghan refugees. elicited the fact that the topic of hirth spacing is sometimes discussed iusually at the request of the patientl but in a very discrect manner and mannly in the context of a woman's health.

The L IRISD surter. The main obiective of this survel of Afghan refugees was to obtain informatton on economic characteristics, such as pre-meration oceupational skills and training. current and potential earnings. and willingness colearn new skills. A stratilied tho-stage random samping procedure uas used to obtain a sample of 2298 houscholds. A male and a female respondent from each were interviewed hy an intervieuer of the same sex (Christensen \& Scott. 1988). Some of the important findings of this survey are: $70^{\circ} \%$ of the respondents were farmers: $40^{\circ} \%$ of male and 3 " of female respondents were literate: two-thirds of males and one in nine femaies laged 18.49 were gainfully employed: most women were sell saployed at home in embroidery sewing. elc: median and mean houschold incones were $R s .360$ and Rs 570 per month respectively: 75 " of houschold income inot counting aid was from empioyment. 15\%, from livestock and poultry. and $5 \%$ from veratables: about $70 \%$ of the houscholds had insufficient income to cover minimal neads: two earners per houschold are required to cover minimal needs: it takis 2 years for a refugec household to settle down to the new enployment and income: $20^{\circ} \%$ of households were unregistered. Of the remainder: $30^{\circ} \%$ had all members resistered: $50^{\circ} \%$ hald one or more members unregistered: $6 \%$ had more registered persons than the actual number of household members. Average househoid size was 8.5 persons. including hoth the registered and other members.

In the LNRISD survey information on age. sex and other characteristics of all household members was obtained irrespective of their registation status. The population pyramid for Afghan refugees. based on the LNRISD data. is compared (Fig. 2) with a pyramid based on the 1972-73 demographic survey conducted in Afghanistan. The overall sex ratio among Afghan refugees was 95 males per 100 females. compared to 116 males per 100 females in Afghanistan before the war. There are considerably higher fertility levels among Afghan refugees. Given that the crude birth rate in Afghanistan for 1972-73 was 43 per 1000. the LNRISD data (Fig. 2) corroborate the atuthor's assumption that the birth rate a mong the refugees would be no less than 50 per 1000 . Moreover. the lower proportion of adult Afghan refugees compared to the pre-War population in Afghanistan is comparable with the effect of war casualties.

Gallup Pakistan's surrey: The main objective of this survey was to estimate the demographic effect of the Afghan war. It covered a sample of 1963 nuclear families in Afghan refugee camps in Pakistan. Information was collected on all family members living in April 1978 when the Comniunist coup took place in Afghanistan. The respondents were then asked to add to this information all births and deaths. together with precise causes and circumstances of death. Other data collected included migration routes to Pakistan. socioeconomic characteristics and ethnic background of the sumpled families.

Among the most significant findings of this survey was the extent to which war 
casualties affected the demography of Afghanistan. It is estimated that the war accounted for daaths of about $9 \%$ of the population. From this figure. the number of Aghans killed is estimated to lie between one and one and a half million people. depending upon the size taken for the pre-war population which was between 12 and 15.5 million (Siwinski. 1988 ).

\section{Other statistics}

Other statistics alailable inciude those on maternal and child health and routine data on attendance at the basic health units. classified according to broad diagnostic categories. Although these data are in various stages of completeness and are not yet availabie in a format amenable to detailed statistical and demographic analysis. they give some indication of problems likely to need intervention.

\section{Conclusion}

The data presented in this paper uere collected under unusual circumstances and were subject to varying degrees of error. For example. the information on the size of the refuges population was not collected as part of a statistical exercise. but uas a byproduct of the administration of the refugee camps and hence had inherent problems, as described. Information on the sociodemographic characteristics came mainly from sample surveys which were subiect to both sampling and non-sampling errors. Overall. the quality of the sample survey data seemed reasonable: however. some of the findings. for example. the substantial drop in infant and childhood mortality rates in Afghan refugee camps over a period of 3 years seem doubtful.

Pakistan and. to a lesser extent Iran. have been the two most popular destinations for Afghan refugees. Very little is known about the size of the Afghan refugee population in Iran but figures as high as two million have been quoted. The presence of a large foreign-born population has significant social, economic and political implications for the recipient countries. This is certainly the case in Pakistan.

\section{Acknowledgments}

The author acknowledges the assistance provided by officials of the Government of Pakistan. the United Nations and its specialized agencies, and non-governmental organizations engaged in providing help to Afghan refugees in Pakistan. The author is particularly grateful to the United Nations Population Fund (UNFPA) for allowing him to use material collected during a mission undertaken on their behalf in early 1989. View's expressed are the author's own and not necessirily those of the UNFPA.

\section{References}

Boss. L. P. \& Lliwis. J. lundated) Eraluation of Infant Mortality and Cihildhood Nutritional Status ammeng tfighan Refugees in Pakistan. 1986. Centers for Disease Control. US Public Health Service, Atlanta. Georgia. 


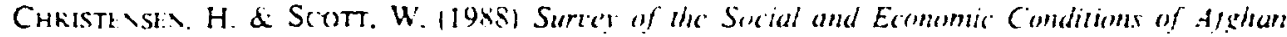
Re-inge'ses in Pukislam. Linited Nations Research lnstutute for Social Develupment. Geneva. Swilzerland.

Hakmi. A. K. \& Graliam. S. (1975) National Demographic and Family Guidance Surtely of the

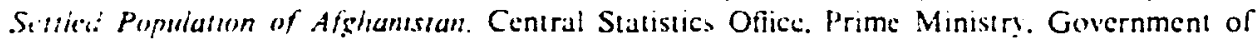
Alghanistan and the LS Agency for International Development.

JWust L. L. 11989, Peshawar bursting uith people and energ!. Pakistan Tinkes. ? February.

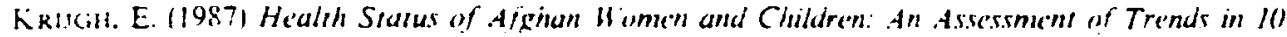
Ri'nerge Camps Be'ween Hangu and Thal. IHFP. Pakisfan. International Rescuc Committee. Posbauar. Pakistan.

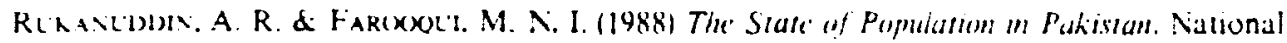
Insulute of Ponulation Studies. Islamabad. Pakistan.

Sumisski. M. (1988), Afghanistan: the decimation of a people. Orbis. 33. 39.

Recrived 2nd Noremher 1989

\section{Appendix}

Table A. Some demographic parameters for Afghanistan. 1972-73

\begin{tabular}{|c|c|c|c|}
\hline Parameter & Total & Urban & Rural \\
\hline Average houschold size & 623 & 6.60 & 6.17 \\
\hline Overall sex ratio & 115.6 & 114.9 & 115.9 \\
\hline Crude birth rate (per 1000 ) & 43 & 38 & $H$ \\
\hline Tolal fertifity rate (per woman) & 6.9 & $5 \cdot 9$ & $7 \cdot 1$ \\
\hline \multicolumn{4}{|l|}{ Crude death rate (per 1000 ) } \\
\hline Both sexes & 210 & $13 \cdot 0$ & $22 \cdot 4$ \\
\hline Males & $20 \cdot 4$ & $12 \cdot 9$ & $21 \cdot 8$ \\
\hline Females & $21 \cdot 6$ & 132 & $23 \cdot 1$ \\
\hline \multicolumn{4}{|l|}{ Infant mortality rate (per 1000 ) } \\
\hline Both sexes & 184.9 & $130 \cdot 7$ & 1932 \\
\hline Miales & $208 \cdot 2$ & $154 \cdot 4$ & 216.4 \\
\hline Females & $160 \cdot 8$ & $106 \cdot 8$ & $169 \cdot 2$ \\
\hline
\end{tabular}

Source: Hakimi \& Graham (1975). 